NASA Technical Memorandum 102113

AIAA 89-2739

\title{
Liquid Oxygen Cooling of Hydrocarbon Fueled Rocket Thrust Chambers
}

Elizabeth S. Armstrong

Lewis Research Center

Cleveland, Ohio

Prepared for the

25th Joint Propulsion Conference

cosponsored by the AIAA, ASME, SAE, and ASEE

Monterey, California, July 10-12, 1989

\section{N/SN}

(NASA-TH-102113) LIQUID OXYGEN COOLING OF

N $89-24447$

HYDROCARBON FUELED ROCKET THRUST CHAMBERS

(NASA. Lewis Research Center) 15 PCSCL $21 \mathrm{H}$ 


\begin{abstract}
$=$
\end{abstract}




\title{
LIQUID OXYGEN COOLING OF HYDROCARBON FUELED ROCKET THRUST CHAMBERS
}

\author{
Elizabeth S. Armstrong* \\ National Aeronautics and Space Administration \\ Lewis Research Center \\ Gleveland, Ohio 44135--3191
}

\begin{abstract}
Rocket engines using liquid oxygen (LOX) and hydrocarbon fuel as the propellants are being given serious consideration for future launch vehicle propulsion. Normally, the fuel is used to regeneratively cool the combustion chamber. However, hydrocarbons such as RP-1 are limited in their cooling capability. Another possibility for the coolant is the liquid oxygen. Combustion chambers previously tested with LOX and RP-1 as propellants and LOX as the coolant have demonstrated the feasibility of using liquid oxygen as a coolant up to a chamber pressure of $13.8 \mathrm{MPa}(2000 \mathrm{psia})$. However, there has been concern as to the effect on the integrity of the chamber liner if oxygen leaks into the combustion zone through fatigue cracks that may develop between the cooling passages and the hot gas side wall.
\end{abstract}

In order to study this effect, chambers were fabricated with slots machined upstream of the throat between the cooling passage wall and the hot gas side wall to simulate cracks. The chambers were tested at a nominal chamber pressure of $8.6 \mathrm{MPa}$ (1247 psia) over a range of mixture ratios from 1.9 to 3.1 using liquid oxygen as the coolant. The results of the testing showed that the leaking LOX did not have a deleterious effect on the chambers in the region of the slots. However, there was unexplained melting in the throat region of both chambers, but not in line with the slots.

\section{INTRODUCTION}

Preliminary design studies ${ }^{1,2}$ for future space transportation systems have shown a need for high pressure booster engines using liquid oxygen (LOX) and a hydrocarbon fuel as the propellants. The candidate hydrocarbon fuels for future launch systems are R $\mathrm{P}-1$, propane, and methane.

Typically, the fuel in a rocket engine is used to regeneratively cool the combustion chamber. The disad- vantage of RP-1, and even the lighter paraffinic hydrocarbon propane, is decomposition (coking) in the cooling passages and corrosion of the copper wall by trace amounts of sulfur-containing compounds. However, recent testing ${ }^{3}$ has shown that RP-1 and methane can be used as coolants at coolant side wall temperatures up to $304^{\circ} \mathrm{C}\left(580^{\circ} \mathrm{F}\right)$ and $499^{\circ} \mathrm{C}\left(930^{\circ} \mathrm{F}\right)$, respectively, without coking or corrosion if there are no sulfur-containing compounds present.

Because of the problems associated with hydrocarbon regenerative cooling, liquid oxygen is being considered as an alternative coolant. There are two concerns with LOX as a coolant: 1) its effectiveness as a coolant, and 2) its effect on the chamber liner if cracks develop. Analyses ${ }^{1,4}$ and experimental work ${ }^{5-7}$ have shown that oxygen can cool rocket engines at chamber pressures up to $27.6 \mathrm{MPa}(4000 \mathrm{psia})$ and $8.6 \mathrm{MPa}$ (1250 psia), respectively, and still maintain reasonable pressure drops. In the experimental work fatigue cracks developed in the throat regions at chamber pressures of $4.1 \mathrm{MPa}(600$ psia) and $8.6 \mathrm{MPa}(1250 \mathrm{psia})$ and the leaking LOX coolant had no effect on the chamber wall. However, there was still some concern as to whether oxygen leaking through cracks between the injector and the throat, where the boundary layer has not been fully developed and there is still combustion occurring, would affect the integrity of the thrust chamber.

The objective of this program was to evaluate the effect of oxygen leaking int the combustion zone through cracks upstream of the thrust chamber thrnat, and to arquire more experience using liçuid oxygen as a coolant. Two thrust chambers had slots machined upstream of the throat between the cooling passage wall and the hot gas side wall to simulate cracks. These LOX-cooled thrust chambers were tested at a nominal rhamber pressure of $8.6 \mathrm{MPa}(1247$ psia) over a range of mixture ratios from 1.9 to approximately 3.1 . This paper presents the results of those tests.

\footnotetext{
-Aerospace Engineer, member AIAA
} 


\section{APPARATUS}

Injector

Figure 1 shows a 61-element triplet injector with 4 radial rings of elements and a central quad element that provided 3 oxidizer streams impinging on a straight fuel stream. The three innermost radial rings were arranged in an oxidizer-fuel-oxidizer $(\mathrm{O}-\mathrm{F}-\mathrm{O})$ sequence to provide good propellant mixing, fuel vaporization, and mass flux distribution. The outermost radial ring consisted of $\mathrm{F}-\mathrm{O}$ doublet showerheads to provide more fuel in the outer zone, which resulted in film cooling of the clamber wall. More details of the injector are given in table $\mathrm{I}$.

\section{Resonator}

A water-cooled resonator, as shown in figure 2 , was used in this investigation to provide stable combustion. It was composed of 16 acoustic cavities arranged evenly around its inside surface. The resonator was placed between the chamber and the injector. The cavities were in line with the chamber at its edge and were $3.63 \mathrm{~cm}$ (1.43 in.) long. The injector formed the inner wall of the cavities which was $2.54 \mathrm{~cm}(1.0 \mathrm{in}$.) long. This corresponded to a quarter wave tube to dampen the second tangential frequency of 9700 cycles/sec which was the expected frequency of the combustion oscillations driving the instability. The hydrogen-oxygen spark torch igniter was located in the resonator wall just downstream of the acoustic cavities.

\section{Combustion Chamber}

Figure 3 shows the dimensions of the combustion chambers used in this test program. The hot gas liners were fabricated from oxygen-free, high conductivity (OFHC) copper and contained 100 axial milled channels for the coolant passages. The passages were closed out with electroformed nickel. The details of the coolant channel dimensions are shown in figure 4 .

Two combustion chambers were tested in this program. Chamber 702 is shown in figure 5 during a firing. To determine the effects of cracks occurring upstream of the throat, both chambers were fabricated with two machined slots $180^{\circ}$ apart. The machined slots were not in the same circumferential location in the two chambers relative to the injector. Instead, the slots in chamber 702 were $45^{\circ}$ off from those in chamber 703 . The slots were $1.0 \mathrm{~cm}(.40 \mathrm{in}$.) long and .0127 $\mathrm{cm}$ (.05 in.) wide. On chamber 702 , the machined slots were located $7.0 \mathrm{~cm}(2.75 \mathrm{in}$.) upstream of the throat, and on chamber 703 they were located $19.0 \mathrm{~cm}$ ( 7.5 in.) upstream of the throat, as shown in figure 6 . Figure 7 shows a close-up view of one of the slots in chamber 702 . The thrust chambers were instrumented with Chromel/Constantan thermocouples imbedded in the rib between coolant channels approximately 1.30 $\mathrm{mm}$ (.051 in.) from the hot gas wall. Both chambers had 20 thermocouples evenly spaced at 4 circumferential locations in 5 axial positions. As shown in figure 6 , the axial positions were $24.13 \mathrm{~cm}$ (9.50 in.) upstream of the throat, $16.50 \mathrm{~cm}(6.50 \mathrm{in.})$ upstream of the throat, $4.44 \mathrm{~cm}(1.75 \mathrm{in}$.) upstream of the throat, at the throat, and at the machined slots. The LOX in the coolant passages used a separate feed system from the LOX flowing through the injector. The LOX coolant was countercurrent to the combustion gases and flowed at approximately the same flowrate as the LOX used as the oxidizer.

\section{Test Facility}

This program was conducted at the NASA Lewis Research Center Rocket Engine Test Facility, a $222400-\mathrm{N}$ (50 000 lbf) sea-level rocket test stand equipped with a water-cooled exhaust-gas muffler and scrubber. The scrubber cools the exhaust gases by spraying them with 1200 liters $/ \mathrm{sec}(10000 \mathrm{gal} / \mathrm{min})$ of water. Details of the facility are shown in figures 5 . Figure 5 shows the thrust stand above the exhaust-gas scrubber with chamber 702 mounted in place. Control room operations during testing included monitoring of the test hardware by means of two closed-circuit video cameras and one test-cell inicrophone. The output of one video camera and the microphone is recorded on video tapes for later playback. Two high speed photographic cameras record each firing at a rate of 400 frames $/ \mathrm{sec}$. Also, a $35 \mathrm{~mm}$ camera photographs the firings at 2 frames/second for still pictures.

During each test, data is recorded using a transient data acquisition and recording system that records data every .02 seconds and averages the data over 5 recordings, with the average reported every 0.1 seconds. The data is then transferred to a centrally located mainframe computer so that it can be easily accessed.

\section{TEST PROCEDURE}

The combustion clambers were tested at a nominal chamber pressure of $8.6 \mathrm{MPa}(1247$ psia) and over a mixture ratio $(0 / \mathrm{P})$ range of 1.91 to 3.10 . Talue 11 gives the test conditions for the test series. The hydrogenoxygen torch igniter. inserted into the combustion area through a port in the resonator, was started prior to the main propellant flow and supplies the energy necessary to start the $\mathrm{LOX} / \mathrm{GH}_{2}$ combustion. Before RP1 was brought into the injector, gaseous hydrogen was introduced throngh the RP-1 line and LOX through a separate line as the chamber pressure was brought up to $1.70 \mathrm{MPa}(246 \mathrm{psia})$ to insure smooth ignition. After approximately 0.8 second, the chamber pressure was 
ramped up to $8.6 \mathrm{MPa}$ (1247 psia) in 0.3 second with RP-1 and LOX propellants. With the RP-1 valve to the tank open, this chamber pressure was maintained for 0.6 second. Then the RP-1 valve was closed and a nitrogen purge was brought on. The purge maintained the chamber pressure for another 0.4 second as it emptied the feed line of RP-1. Then the purge was diminished and the LOX propellant valve closed. The LOX coolant valve was closed after the propellant valves to cool the chamber after firing and to keep combustion products from entering the coolant passages through the machined slots.

Test cycles were programmed into a solid-state timer that is accurate and repeatable to within $\pm 0.001 \mathrm{sec}$. Fuel and oxidizer flows were controlled by fixed-position valves and propellant tank pressure. Coolant inlet pressure was controlled by coolant tank pressure. Coolant exit pressure was kept constant by a closed-loop controller positioning a back pressure valve. After its use, the coolant was vented to the atmosphere through a prechilled vent and the coolant vent line was purged after each test to insure that all the coolant had been vented. The exhaust gases were directed into a watercooled scrubber where they were cooled by water sprays flowing at 1200 liters $/ \mathrm{sec}(19000 \mathrm{gal} / \mathrm{min})$, precipitating unburned RP-1. The water sprays also muffled the noise from combustion. After use in cooling the exhaust gases, the water was retained in a detention tank and then cycled through a waste treatment plant where all unburned RP-1 was trapped and disposed of properly.

Between runs, the injector was purged to keep the injector clean of dirt. The processed data was available in the control room from the mainframe computer within minutes after a test. This access allowed for review of the processed data prior to the next test.

\section{RESULTS AND DISCUSSION}

Chamber 702 was fired twice. The chamber was inspected after one run and a melted region was detected just upstream of the throat and at the throat. Several oxygen-rich zones were also detected from discoloration of the copper wall. The zones, which appear as streaks, began at the injector face and continued past the throat region. The melted region was in line circumferentially with an oxygen-rich streak from the injector but not in line with either machined slot. During the second run, the RP-1 flow decreased, for reasons not yet determined. As a result, the mixture ratio increased from about 2.39 at the beginning of the test to 3.72 at the end, passing through the stoichiometric mixture ratio of 3.43. The chamber was inspected after the second run and there was indication of more melting in the same location, which opened up several coolant passages (figure 8), The reason for the severe melting is presently undetermined. The injector was not damaged, but in one area, the injector elements were discolored, indicating a hot spot. Chamber 702 was then taken off the test stand and sectioned. Figure 7 shows the slot closest to the melted region. As can be seen, there is no distinguishable effect from the leaking LOX in the region of the slot. Figures 9 and 10 show the damage to the throat area and upstream of the throat in relation to a machined slot and an oxygen-rich streak.

Six complete runs and one partial run were conducted with chamber 703 . After the first three runs, the chamber was inspected and no evidence of damage was detected on the liner surface. The chamber was fired four more times and then inspected again. A part of the cliamber liner had melted at the throat and just upstream of the throat (figure 11). Several oxygen-rich streaks were also detected from discoloration of the copper wall. The streaks began at the injector face and continued past the throat. The melted region was in line circumferentially with an oxygen-rich streak from the injector but not with either machined slot (figure 12). Again, the reason for the melting is presently undetermined. Chamber 703 was then taken off the test stand and also sectioned. Again, there was no distinguishable effect on the chamber from the leaking LOX at the machined slots.

Figure 13 shows the melted region at the throat for the two chambers. The line on the outside of each section represents the same circumferential location relative to the injector face. As can be seen, the melted regions were not in the same circumferential location.

\section{Injector Performance}

Figure 14 is a plot of the $\mathrm{C}^{*}$ efficiency (characteristic exhaust velocity efficiency) versus the mixture ratio tested. As expected, the $C^{*}$ efficiency increased after melting occurred at the throat. The rise in efficiency is a result of the additional mass flow coming into the chamber at the throat that was not accounted for in the $C^{*}$ calculations. The $C^{*}$ efficiency for the slotted chambers is generally higher than the $\mathrm{C}^{*}$ efficiency using identical hardware without machined slots ${ }^{6}$ for the same reason. Figure 15 is a plot of the thrust level versus mixture ratio. This figure indicates that the thrust. level also increased after melting occurred at the throat. due to the increase in mass flow.

\section{Effects of LOX Leaks on Chamber Integrity}

Thermocouples were located on the chambers at the slot locations and $2.54 \mathrm{~cm}(1.0 \mathrm{in}$.) downstream of the slots to determine the effect of LOX leaks on wall temperature. The temperatures $2.54 \mathrm{~cm}$ (1.0 in.) downstream of the slots in chamber $702(4.44 \mathrm{~cm}$ upstream of the throat) are compared for the two chambers in 
figure 16, which shows similar temperatures for the two chambers. Location $B$ on chamber 703 had very high temperatures on runs 33 and 34 although no discernable melting occurred during these runs. The temperatures $2.54 \mathrm{~cm}$ downstream of the slots in chamber $703(16.46$ $\mathrm{cm}$ upstream of the throat) are compared for the two chambers in figure 18 , which shows similar temperatures for the two chambers. Location $B$ on chamber 702 had very high temperatures and was circumferentially near the melted throat region. This axial location, however, is upstream of the slots, indicating that these high temperatures at location $B$ were not caused by the slots, but by the oxygen rich streak which began at the injector face. Figures 16 and 17 do not indicate any increase in temperature due to the slots in the area just downstream of the slots. Also, there was no deleterious effect on the chambers in the region of the slots. However, there were melted regions at the throat but not in line with slots. The cause of the melted regions las not yet been determined.

\section{Possible Causes for Chamber Melting}

A number of theories have been postulated as to the cause of the melting in the throat region of the combustion chambers. The three most plausible theories are discussed here as well as possible methods to determine their validity.

The melting could be a result of an oxygen-rich zone, which appears as a streak, beginning at the injector face and continuing past the throat. The melted regions on both chambers were in line with streaks. However, in previous testing ${ }^{6}$ using the exact injector with similar chambers under similar operating conditions, the chambers had no melted regions after 26 cycles. To explore this theory further, a new injector will be tested using similar chambers with slots upstream of the throat.

A second possible cause of melting is blocked coolant passages. If several coolant passages are blocked, localized hot spots may result in those circumferential locations. The chambers were sectioned and all the channels were closely inspected for any blockage. The coolant passages had been properly machined and no blockage was found anywhere. Therefore, blocked coolant passages are not the cause of the melting.

The third possible cause of melting is the effect from machined slots upstream of the throal. The oxygen flowing through the slots may have reacted with the chamber wall at the throat, resulting in melting. However, from figure 7 , one can see that the oxygen leaking from the slot did not react with the wall near the slot. Also, the slots were not directly in line with the melted region on either chamber. A similar chamber without slots will be tested using the same injector that was used in this program to determine if the slots were the cause of the melting.

\section{SUMMARY OF RESULTS}

Two OFHC copper thrust chambers with identical geometry were tested with LOX/RP-1 as propellants and LOX as the coolant at a nominal chamber pressure of $8.6 \mathrm{MPa}(1247 \mathrm{psia})$ over a mixture ratio $(\mathrm{O} / \mathrm{F})$ range of 1.91 to 3.10 . To determine the effect of leaking LOX upstream of the throat, the thrust chambers were fabricated with slots machined between the cooling passage wall and the hot gas side wall, to simulate cracks. The results of these tests are as follows:

1. LOX leaks through slots in the cooling passage wall did not have a deleterious effect on the thrust chambers in the regions of the slots.

2. There was unexplained melting in the throat region of both chambers; however, the melting was not in line with the machined slots.

3 . The cause of the melting has not yet been determined.

\section{REFERENCES}

1. Luscher, W.P.; and Mellish, J.A.: Advanced High Pressure Engine Study for Mixed-Mode Vehicle Applications. NASA C'R-135141, 1977.

2. Caluori, V.A.; Conrad, R.T.; and Jenkins, J.C.: Technology Requirements for Future Earth-toGeosynchronous Orbit Transportation Systems. NASA CR-3265, 1980.

3. Rosenberg, S.D.; and Gage, M.L.: Compatibility of Hydrocarbon Fuels with Booster Engine Combustion Chamber Liners. AIAA/ASEE/ASME/SAE 24th Joint Propulsion Conference, AIAA paper 88$3215,1988$.

4. Rousar, D.C: and Miller, F.: Cooling with Supercritical Oxygen. AIAA paper 75-1248, 1975.

5. Price, H.G.: Cooling of High-Pressure Rocket Thrust Chambers with Liquid Oxygen. J. Spacecraft and Rockets, Vol. 18, No, 4, 1980, p. 338343 .

6. Price, H.G.: and Masters, P.A.: Liquid Oxygen Cooling of High Presssure LOX/Hydrocarbon Rocket Thrust Chambers. NASA TM-88805, 1986.

7. Dederra, H.; and Kirner, E.: High Pressure Rocket Engine Liquid Oxygen Technology. XXXVII Congress of the International Astronautical Federation, IAF-76-174, 1976. 
TABLE I. - INJECTOR GEOMETRY OF 61 -ELEMENT INJECTOR WITH TRIPLET OXYGEN-FUEL-OXYGEN

TANGENTIAL LIQUID OXYGEN FANS

\begin{tabular}{|c|c|c|c|c|c|c|c|c|}
\hline \multicolumn{3}{|c|}{ Hole diameter, $\mathrm{mm}$ (in.) } & \multicolumn{3}{|c|}{ Flow area, $\mathrm{mm}^{2}$ (in. ${ }^{2}$ ) } & \multirow{2}{*}{$\begin{array}{c}\text { Total } \\
\text { flow } \\
\text { area, } \\
\mathrm{mm}^{2} \\
\left(\mathrm{in},{ }^{2}\right)\end{array}$} & \multirow{2}{*}{$\begin{array}{l}\text { Portion } \\
\text { of total } \\
\text { flow in } \\
\text { outer } \\
\text { zone, } \\
\text { percent }\end{array}$} & \multirow{2}{*}{$\begin{array}{l}\text { Nominal } \\
\text { chamber } \\
\text { pressure, } \\
P_{C} \\
M P_{a} \text { abs } \\
\text { (psia) }\end{array}$} \\
\hline $\begin{array}{l}\text { Outer } \\
\text { zone }\end{array}$ & $\begin{array}{l}\text { Core } \\
\text { zone }\end{array}$ & $\begin{array}{l}\text { Center } \\
\text { zone }\end{array}$ & $\begin{array}{l}\text { Outer } \\
\text { zone, } \\
24 \text { holes }\end{array}$ & $\begin{array}{l}\text { Core } \\
\text { zone } \\
36 \text { holes }\end{array}$ & $\begin{array}{l}\text { Center } \\
\text { zone, } \\
1 \text { hole }\end{array}$ & & & \\
\hline \multicolumn{9}{|c|}{ Fuel element } \\
\hline $\begin{array}{c}1.168 \\
(0.046)\end{array}$ & $\begin{array}{c}1.600 \\
(0.063)\end{array}$ & $\begin{array}{c}1.600 \\
(0.063)\end{array}$ & $\begin{array}{l}25.715 \\
(0.040)\end{array}$ & $\begin{array}{l}72.382 \\
(0.112)\end{array}$ & $\begin{array}{c}2.011 \\
(0.0031)\end{array}$ & $\begin{array}{l}100.111 \\
(0.1551)\end{array}$ & 25.7 & $(1247)^{8.6}$ \\
\hline \multicolumn{9}{|c|}{ Oxidizer element } \\
\hline $\begin{array}{c}1.168 \\
(0.046)\end{array}$ & $\begin{array}{c}1.702 \\
(0.067)\end{array}$ & $\begin{array}{c}1.397 \\
(0.055)\end{array}$ & $\begin{array}{l}25.735 \\
(0.040)\end{array}$ & $\begin{array}{l}163.74 \\
(0.254)\end{array}$ & $\begin{array}{c}4.581 \\
(0.0071)\end{array}$ & $\begin{array}{l}194.05 \\
(0.3011)\end{array}$ & 13.2 & $\begin{array}{r}8.6 \\
(1247)^{8}\end{array}$ \\
\hline
\end{tabular}

TABLE II. - TEST CONDITIONS

\begin{tabular}{|c|c|c|c|c|c|c|c|}
\hline \multirow[t]{3}{*}{ Run } & \multirow[t]{3}{*}{ Engine } & \multirow{2}{*}{\multicolumn{2}{|c|}{$\begin{array}{l}\text { Nominal chamber } \\
\text { pressure, } P_{C}\end{array}$}} & \multirow{3}{*}{$\begin{array}{c}\text { Mixture } \\
\text { ratio, } \\
\text { O/F }\end{array}$} & \multicolumn{2}{|c|}{ Coolant flow rate } & \multirow{3}{*}{$\begin{array}{c}\text { Run } \\
\text { time, } \\
\text { sec }\end{array}$} \\
\hline & & & & & \multirow{2}{*}{$\mathrm{kg} / \mathrm{sec}$} & \multirow{2}{*}{$\mathrm{lbm} / \mathrm{sec}$} & \\
\hline & & $\mathrm{MPa}$ abs & psia & & & & \\
\hline 22 & 702 & 8.329 & 1208 & 2.71 & 12.0 & 26.5 & 1.0 \\
\hline 25 & 702 & 7.963 & 1155 & a 3.10 & 14.7 & 32.4 & 1.0 \\
\hline 32 & 703 & 8.274 & 1200 & 2.58 & 14.1 & 31.1 & 1.0 \\
\hline 33 & 703 & 8.542 & 1239 & 2.78 & 14.4 & 31.8 & 1.0 \\
\hline 34 & 703 & 8.598 & 1247 & 2.72 & 14.3 & 31.5 & 1.0 \\
\hline 35 & 703 & 8.556 & 1241 & 2.33 & 14.2 & 31.2 & 1.0 \\
\hline 36 & 703 & 8.618 & 1250 & 1.91 & 13.9 & 30.7 & 1.0 \\
\hline 37 & 703 & 8.687 & 1260 & 2.10 & 13.4 & 29.5 & .6 \\
\hline 38 & 703 & 8.777 & 1273 & 2.18 & 13.6 & 30.0 & 1.0 \\
\hline
\end{tabular}

aAverage for the entire run.

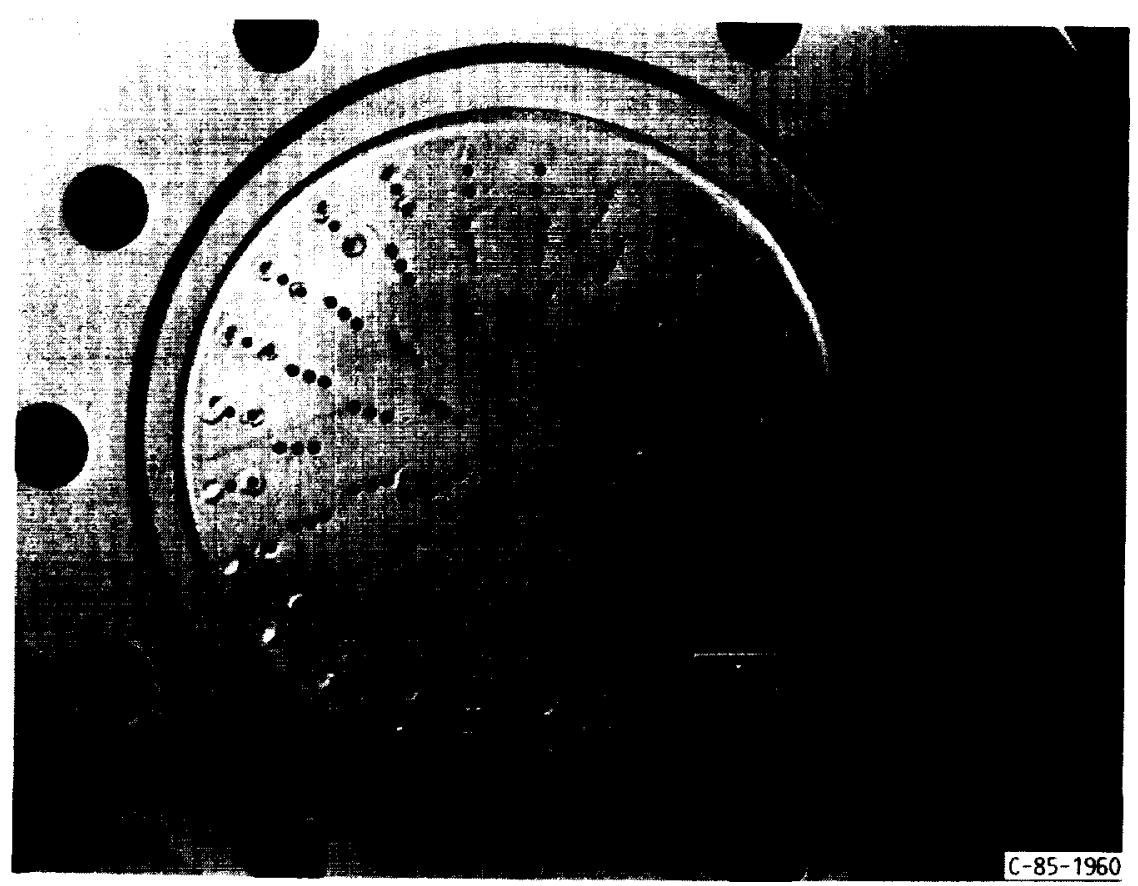

FIGURE 1. - 61 ELEMENT TRIPLET INJECTOR. 


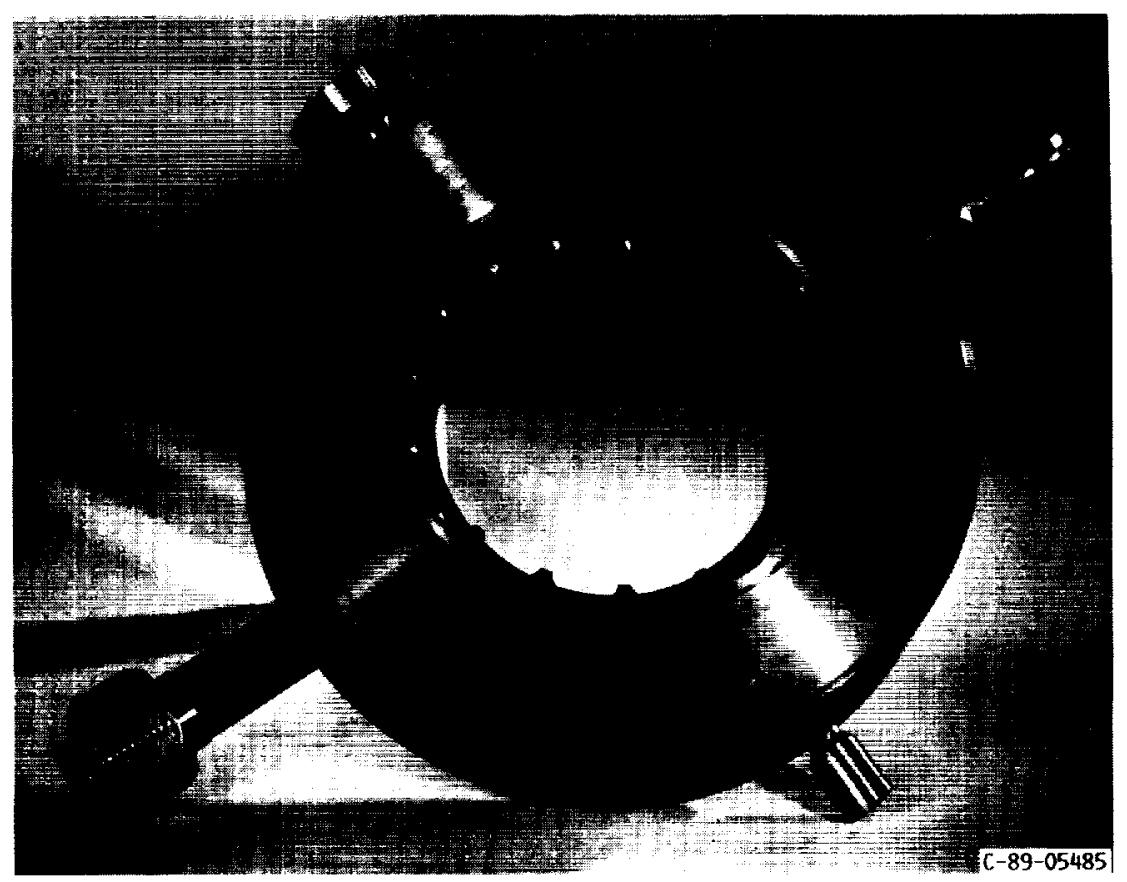

FIGURE 2. - ACOUSIIC RESONATOR.

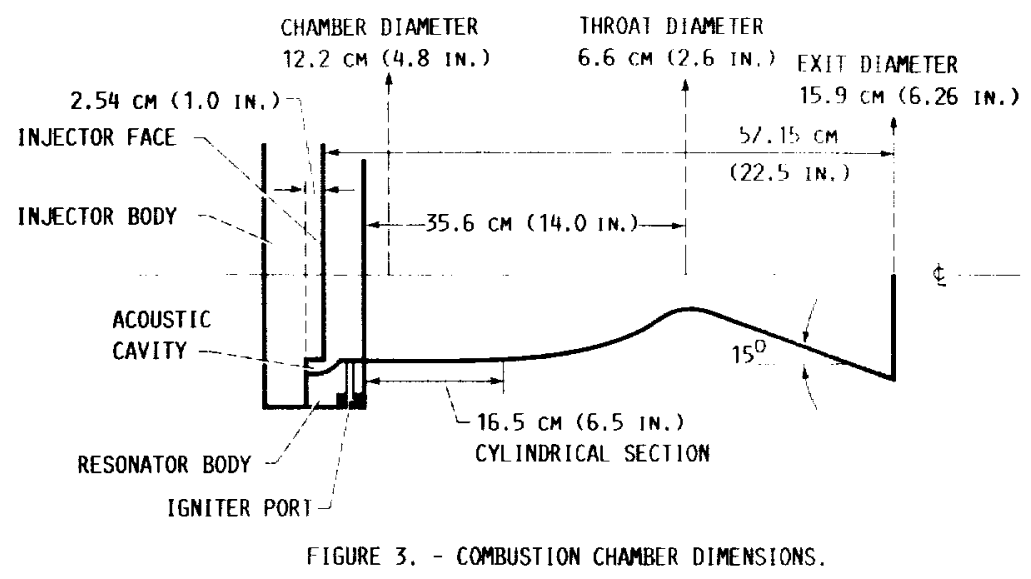

ORIGINAL PAGE

6 BLACK AND WHITE PHOTOORAPH 

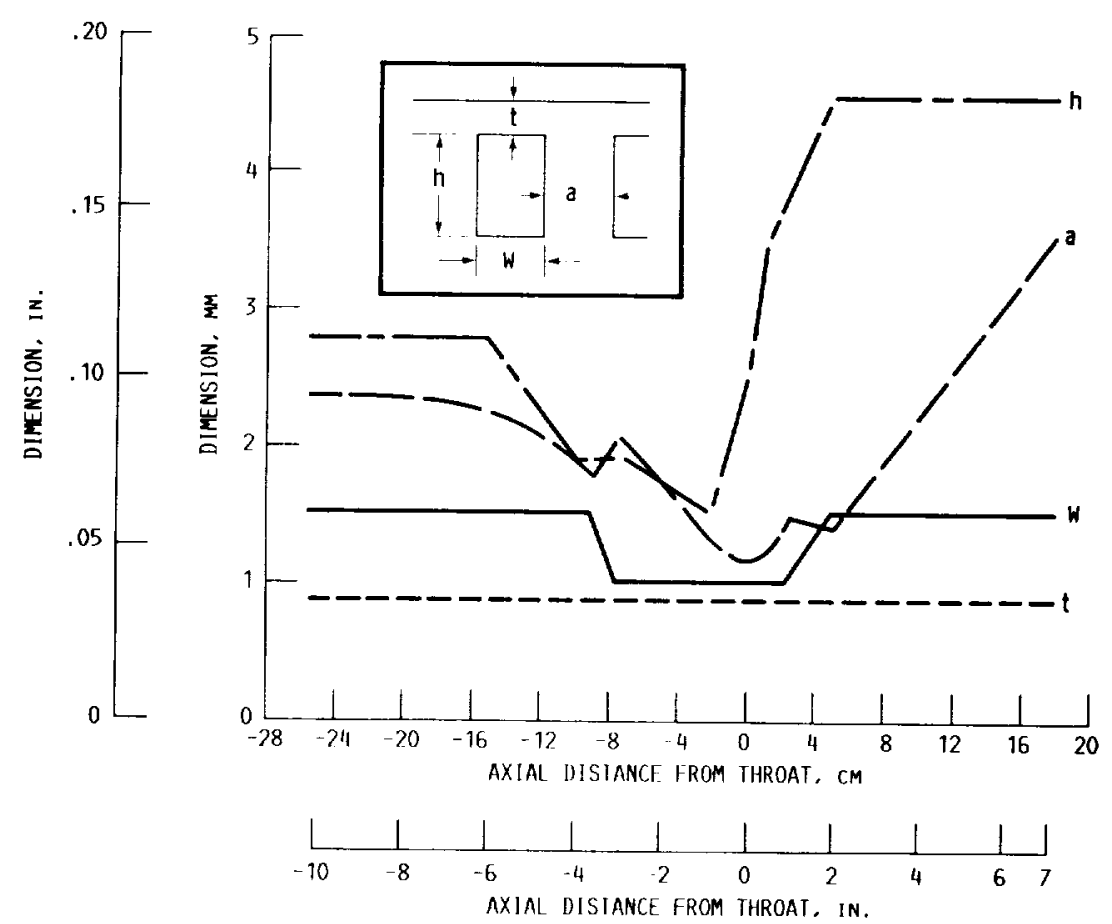

FIGURE 4. - CHAMBER WALL AND CHANMEL DIMENSIONS.

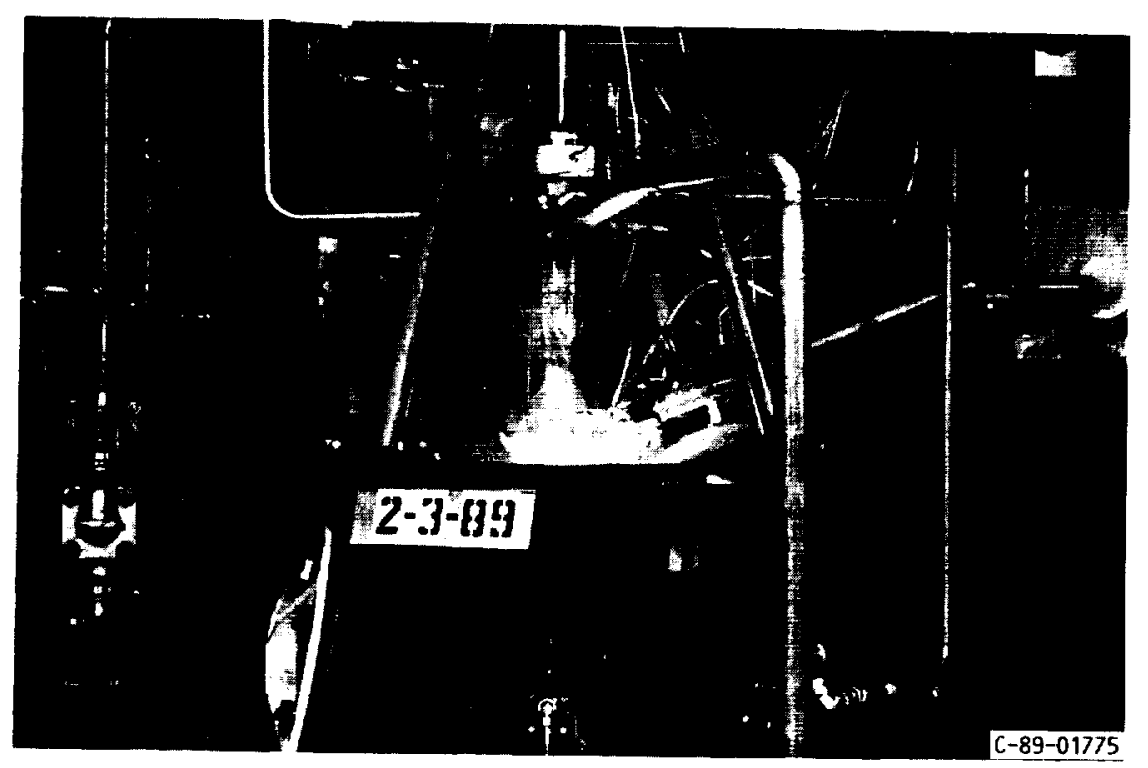

FIGURE 5. - CHAMBER DURING TEST FIRING.

ORIG!NAL PAGE

BLACK ANO WHITE. PHOTORRADH 

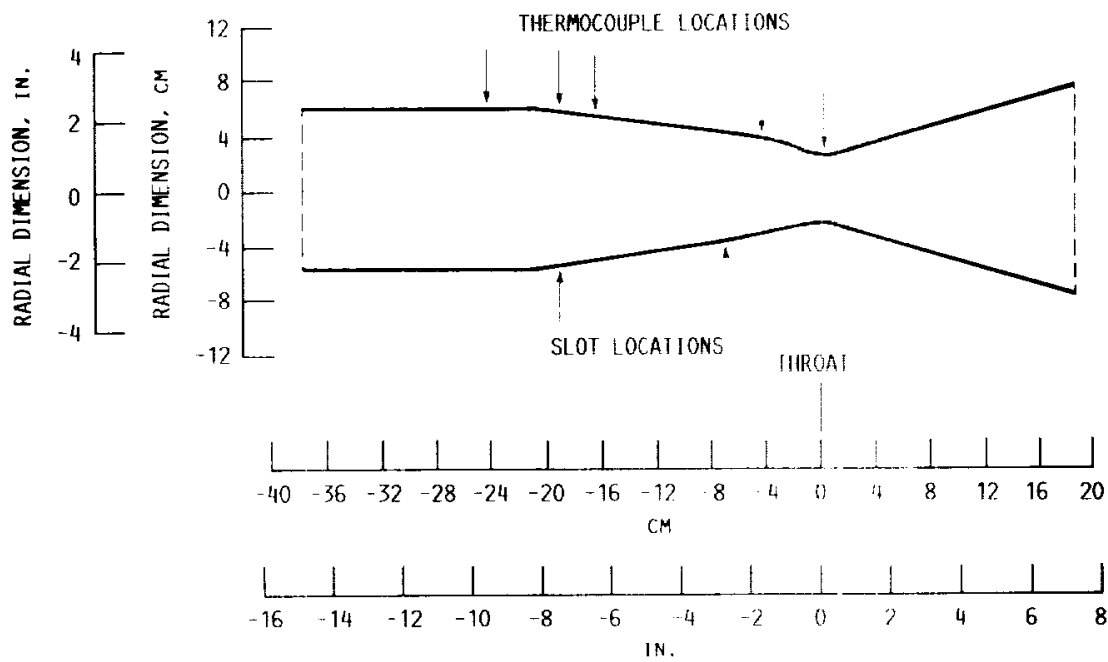

FIGURE 6. - SLOT AND THERMOCOUPLF I OCATIONS.

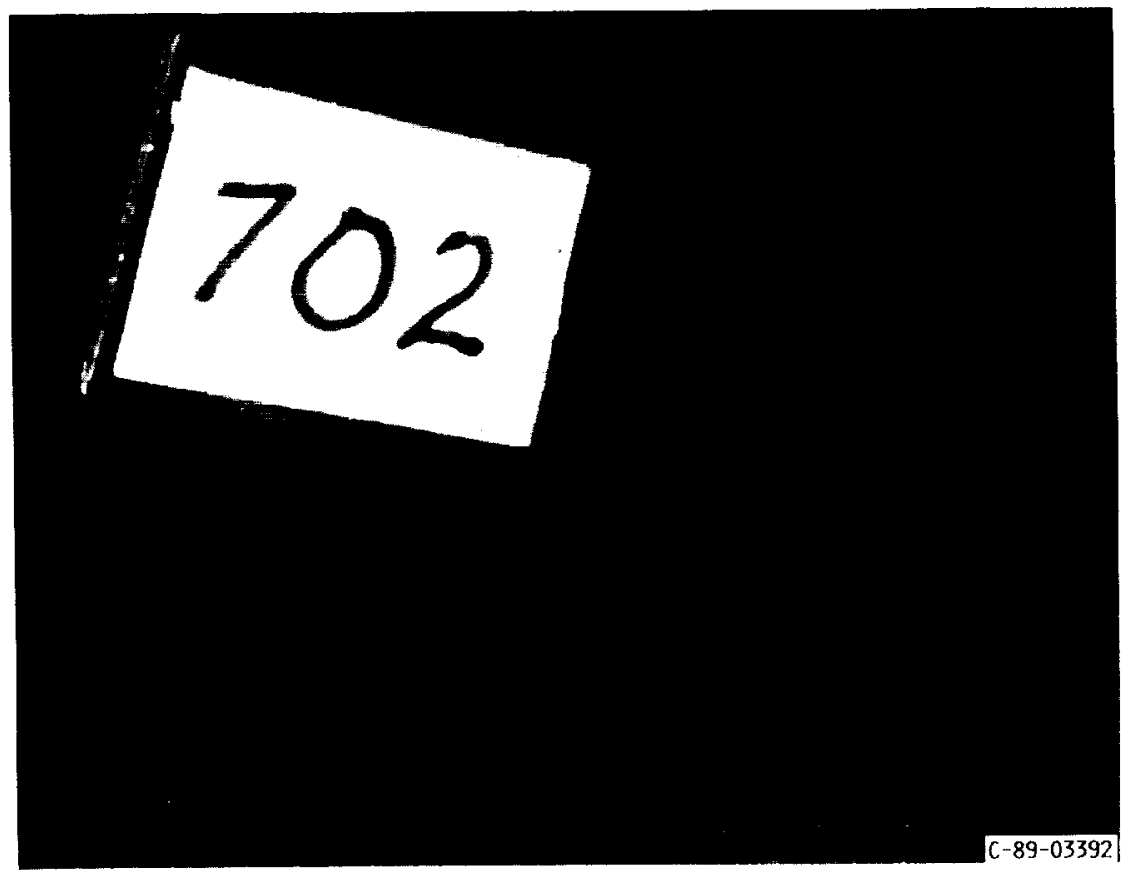

FIGURE 7. - CLOSE UP VIEW OF MACHINE II SI OI. 


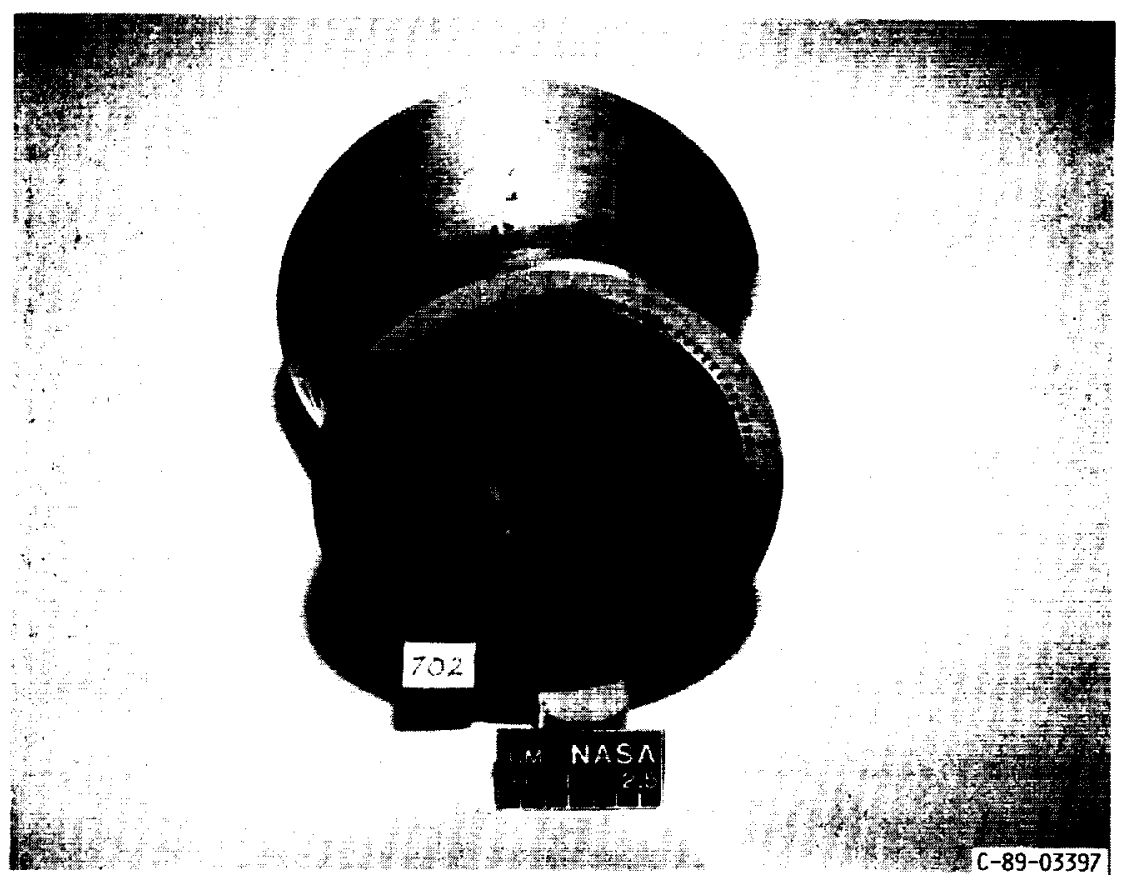

FIgURE 8. - CHAMBER 702 THROAT AREA.

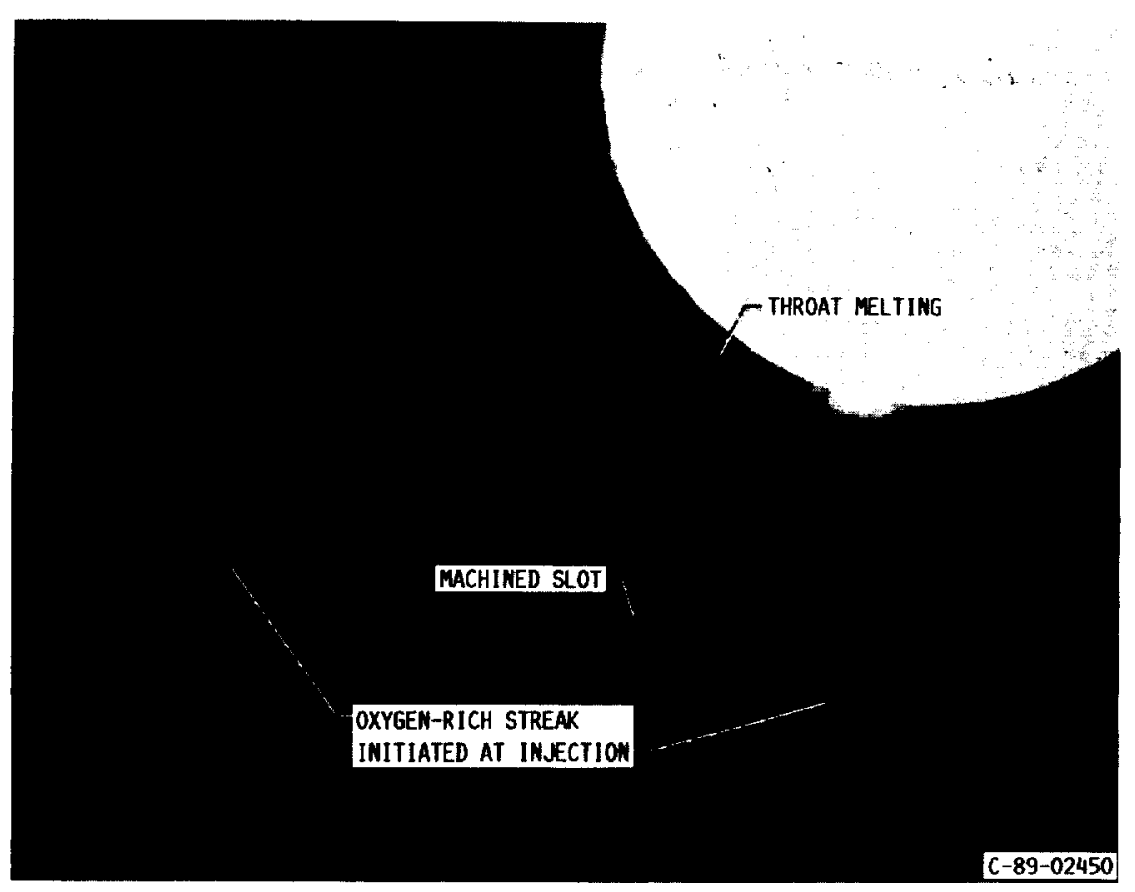

FIGURE 9. - CHAMBER 702 AFTER TESTING. 


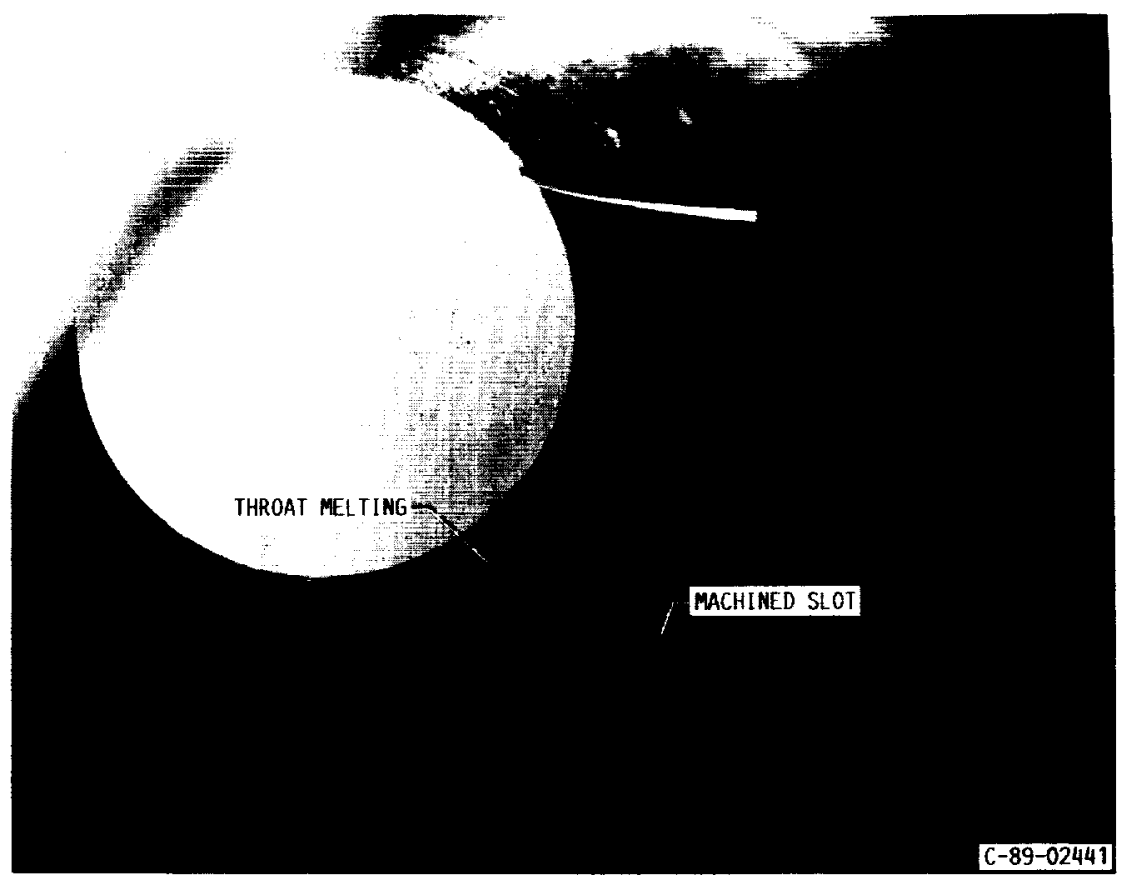

FIGURE 10. - MELTING AT THROAT OF CHAMBER 702.

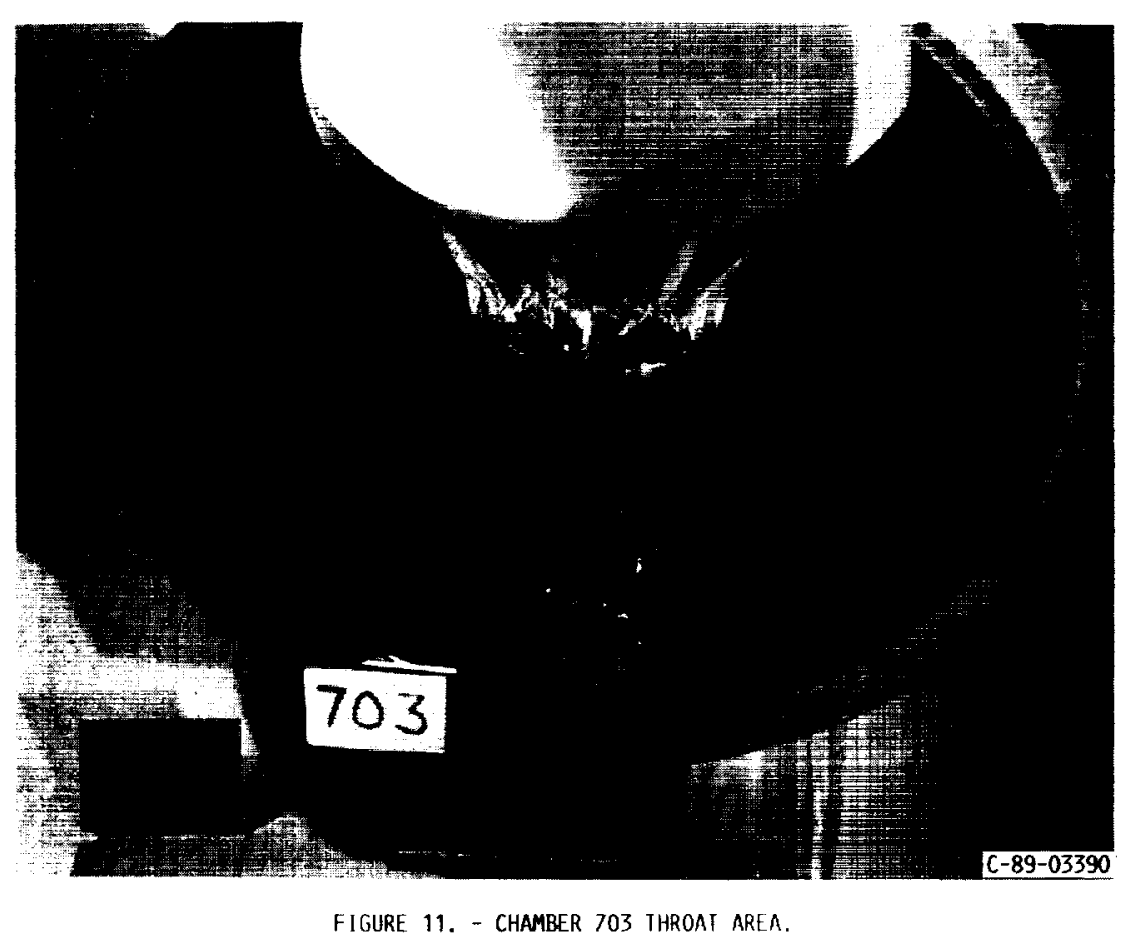

ORIGINAL PAGE 


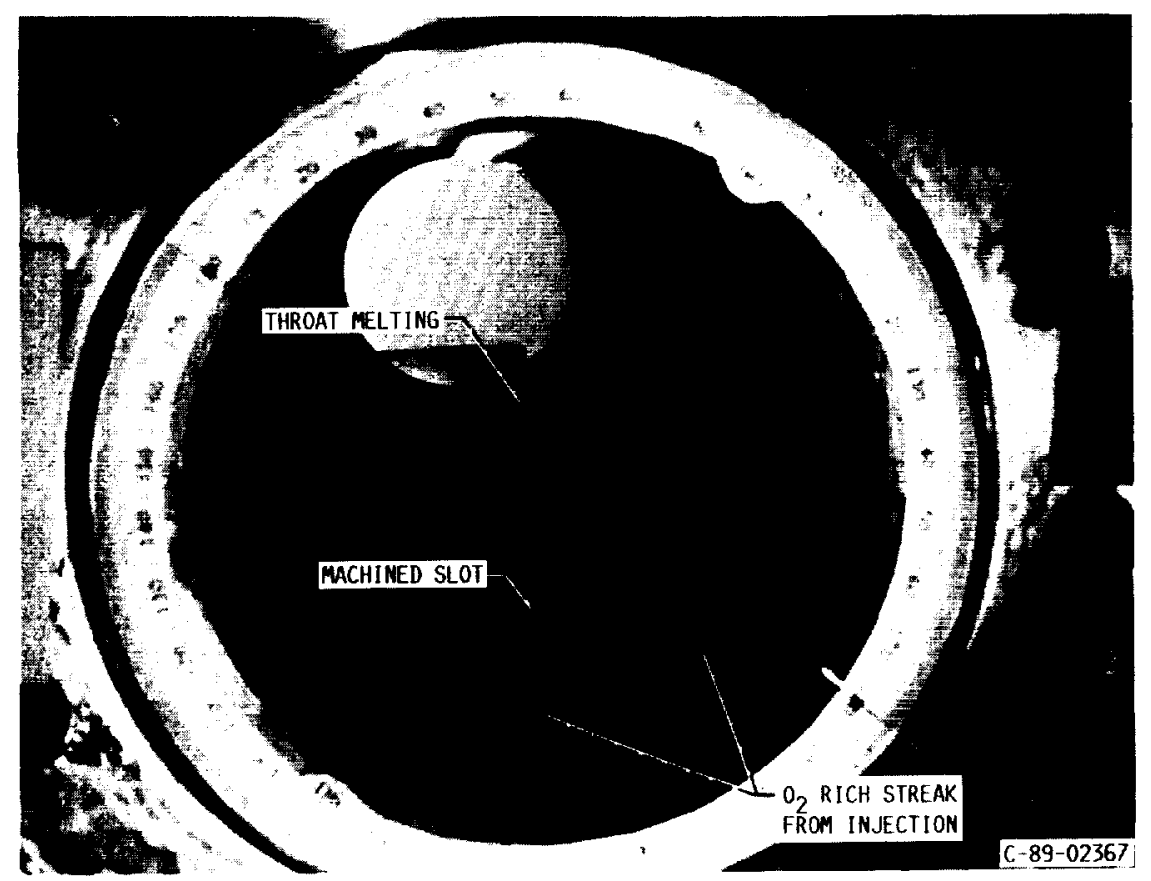

FIGURE 12. - CHAMBER 703 AFTER TESIING.

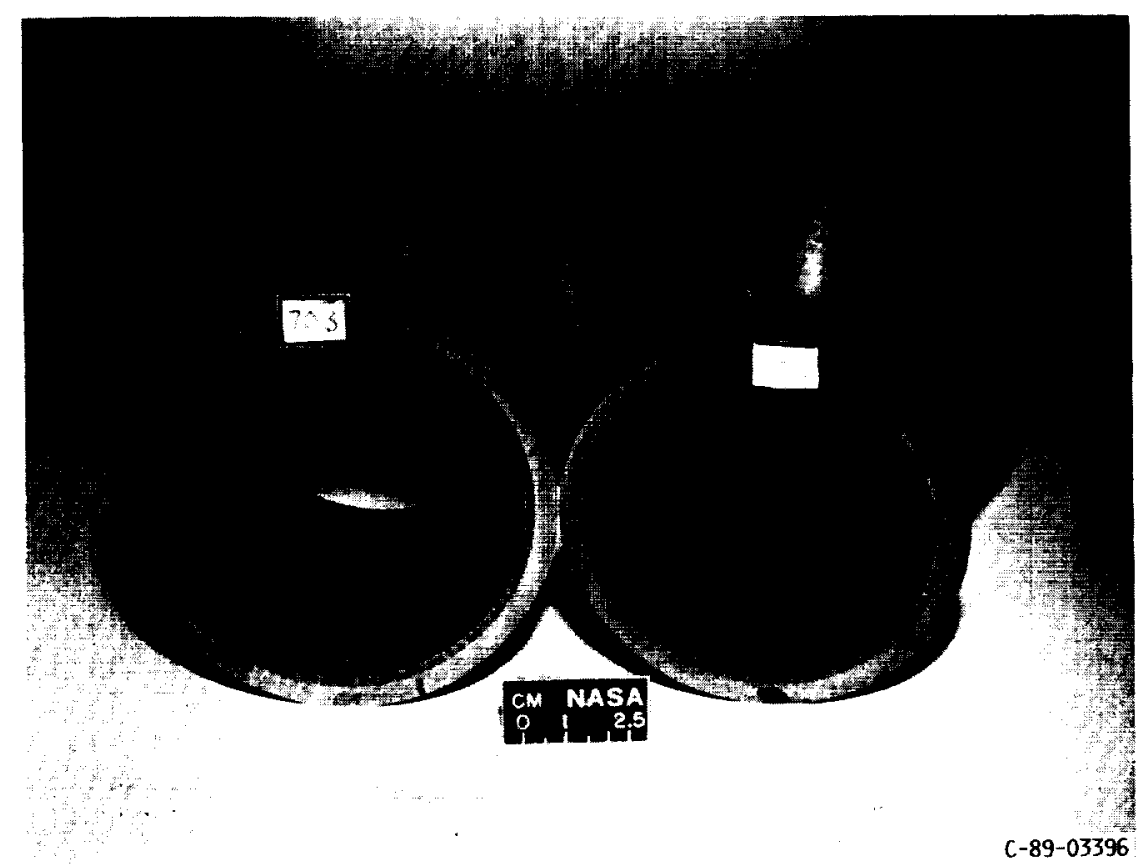

FIGURE 13. - MELTED THROAT REGION OF BOTH CHAMBERS.

\author{
ORIGINAL PAGE \\ BLACK ANO WHITE PHOTOGRAPH
}




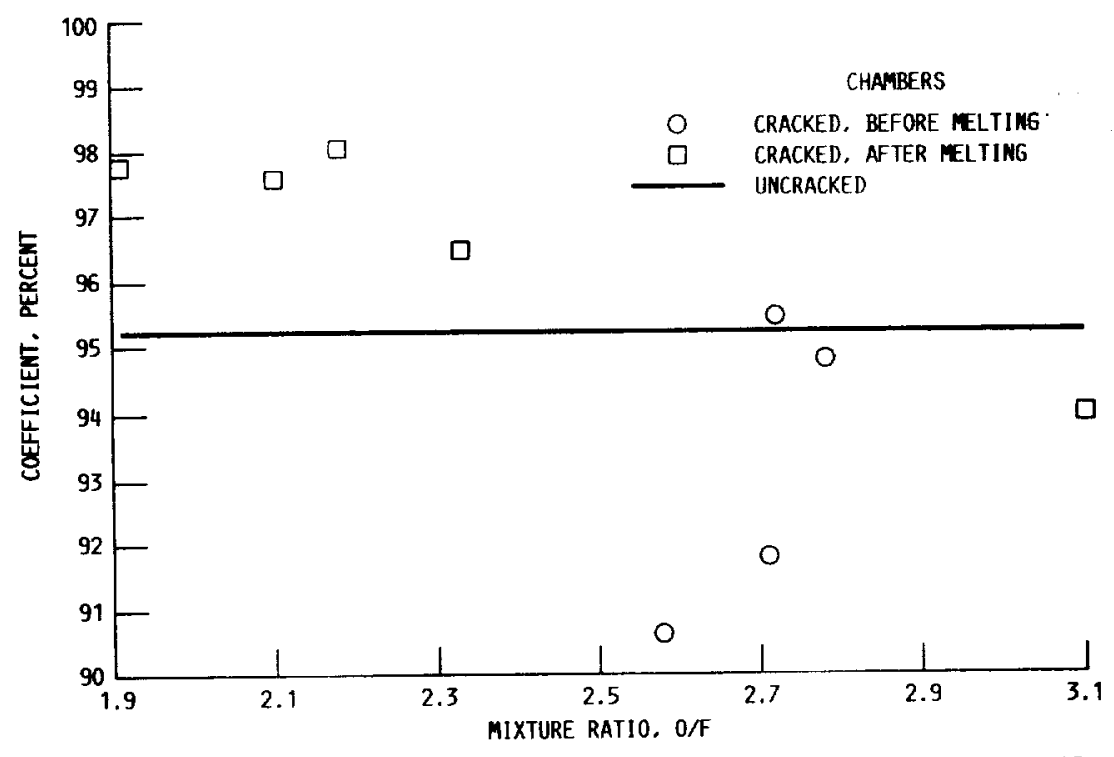

FIGURE 14. - CHARACTERISTIC EXHAUST VELOCITY EFFICIENCY FOR A CHAMBER PRESSURE of $8.6 \mathrm{MPA}$.

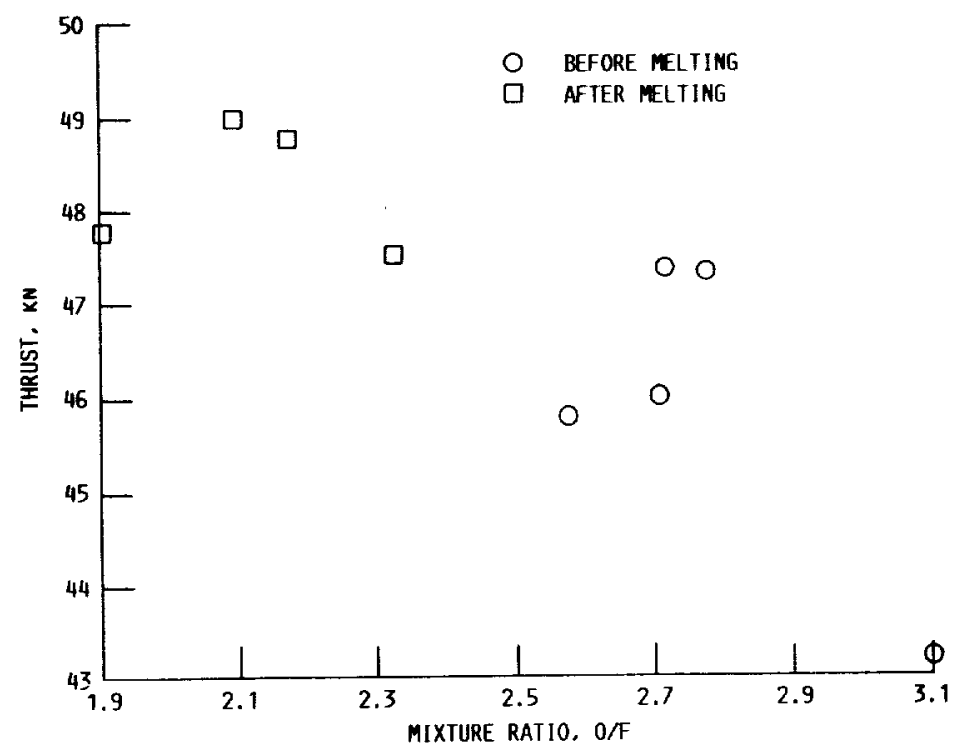

FIGURE 15. - THRUST LEVEL FOR A CHAMBER PRESSURE OF 8.6 PA (1250 PSIA). 


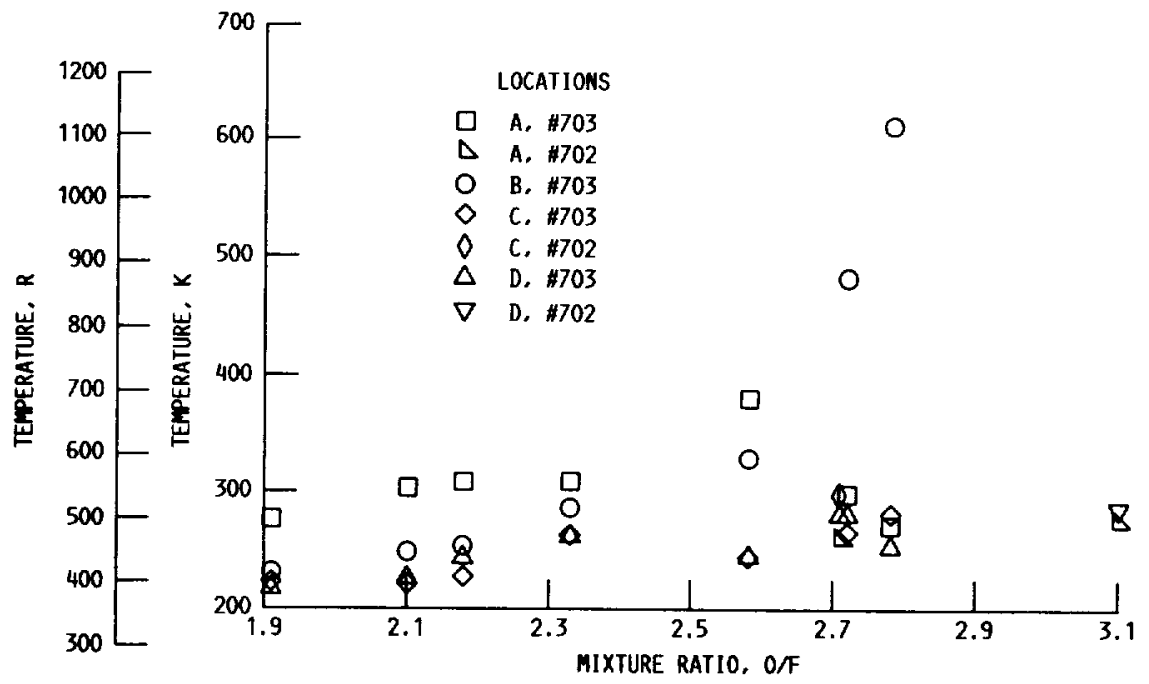

FIGURE 16. - HOT GAS MALL IEMPERATURES, AT $X=4.44 \mathrm{~cm}$.

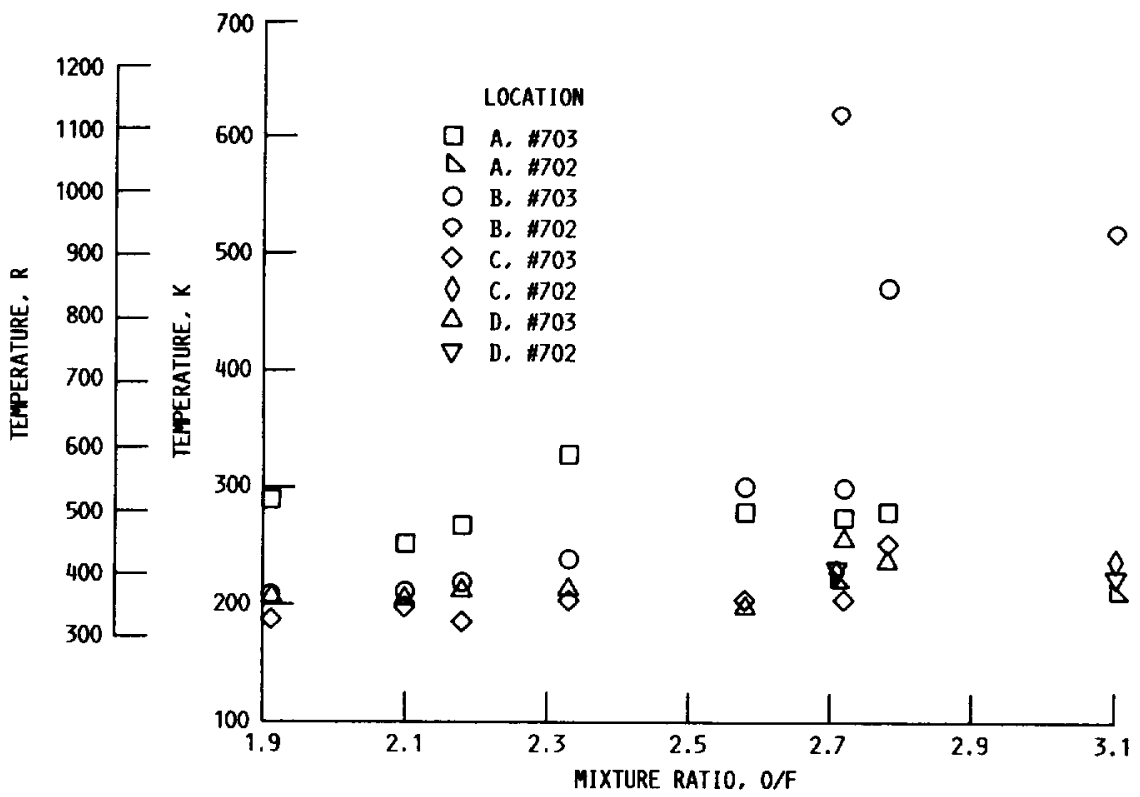

FIGURE 17. - HOT GAS WALL TEMPERATURES AT $X=16.5 \mathrm{~cm}$. 


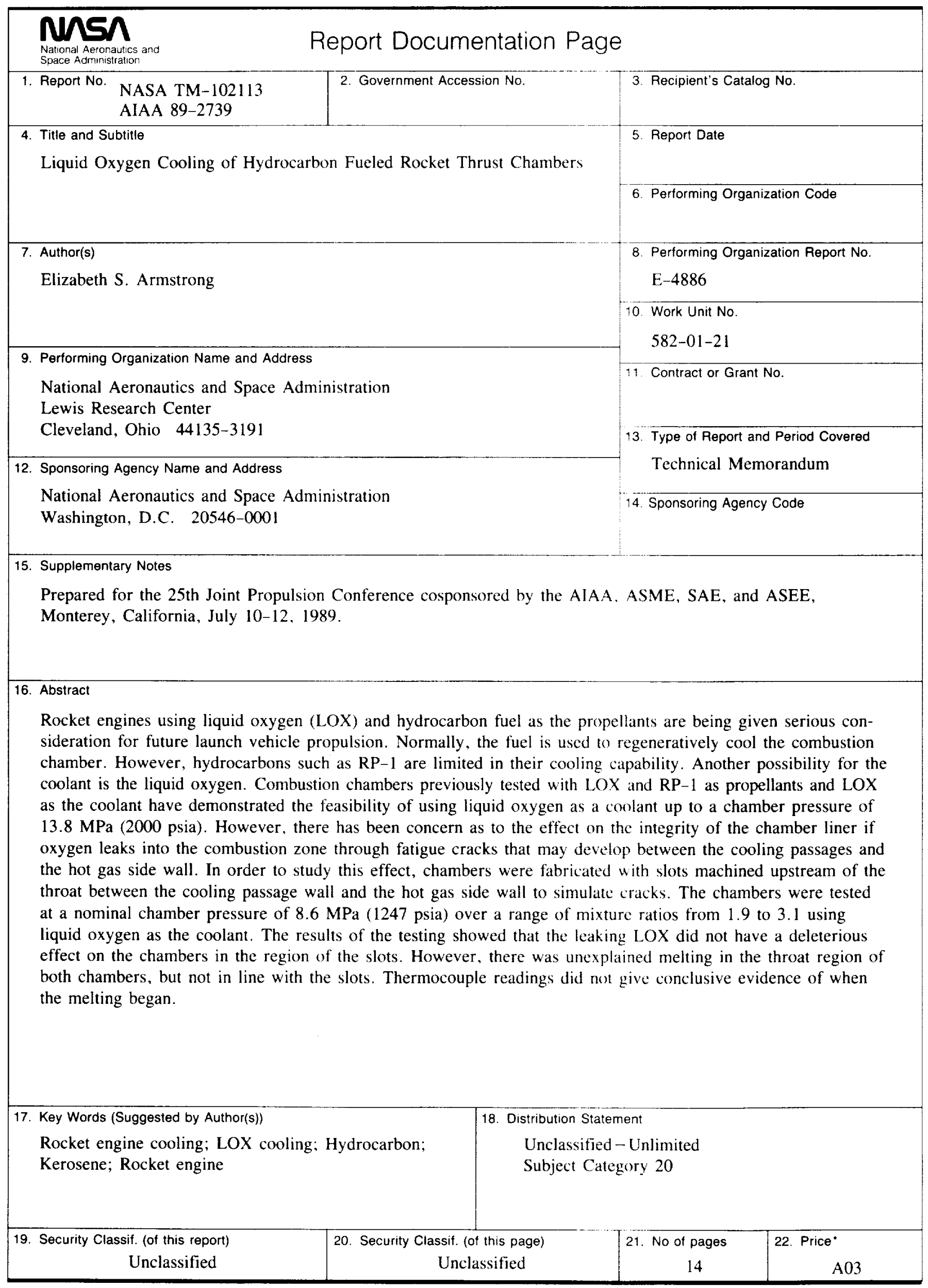

